\title{
Drug resistance in anti-TNF therapy of psoriatic arthritis
}

\author{
Lekooporność w terapii anty-TNF w łuszczycy stawowej
}

\author{
Dominika Ligia Wcisło-Dziadecka', Beniamin Grabarek², Ligia Brzezińska-Wcisło³, Urszula Mazurek²
}
'Department of Skin Structural Studies, Chair of Cosmetology, School of Pharmacy with the Division of Laboratory Medicine in Sosnowiec, Medical University of Silesia in Katowice, Poland
2Department of Molecular Biology, School of Pharmacy with the Division of Laboratory Medicine in Sosnowiec, Medical University of Silesia in Katowice, Poland
${ }^{3}$ Chair and Department of Dermatology, School of Medicine, Medical University of Silesia in Katowice, Poland
'Zakład Badań Strukturalnych Skóry Katedry Kosmetologii Wydziału Farmaceutycznego z Oddziałem Medycyny Laboratoryjnej w Sosnowcu Śląskiego Uniwersytetu Medycznego w Katowicach, Polska
${ }^{2}$ Katedra i Zakład Biologii Molekularnej Wydziału Farmaceutycznego z Oddziałem Medycyny Laboratoryjnej w Sosnowcu Śląskiego Uniwersytetu Medycznego w Katowicach, Polska
${ }^{3}$ Katedra i Klinika Dermatologii Wydziału Lekarskiego Śląskiego Uniwersytetu Medycznego w Katowicach, Polska

\author{
CORRESPONDING AUTHOR/ \\ ADRES DO KORESPONDENCJI: \\ dr n. med. Dominika \\ Wcisło-Dziadecka \\ Zakład Badań \\ Strukturalnych Skóry \\ Katedra Kosmetologii \\ Wydział Farmaceutyczny \\ z Oddziałem Medycyny \\ Laboratoryjnej w Sosnowcu \\ Śląski Uniwersytet Medyczny \\ w Katowicach \\ ul. Kasztanowa 3 \\ 41-200 Sosnowiec \\ tel./faks: +48 32 25-91-580/581, \\ +48 32 256-11-82 \\ e-mail: ddziadecka@interia.pl
}

\begin{abstract}
Introduction. Despite of the molecular targeting anti-TNF therapy, drug resistance may be observed. A method of avoiding this phenomenon, changing treatment early and increasing its effectiveness, the new molecular markers may be used.

Objective. To present clinical (PASI, BSA, DAS28, DLQI) and molecular (TNF- $\alpha, T N F R 1, T N F R 2)$ parameters of loss of efficacy to etanercept in a patient with psoriatic arthritis.

Case report. Patient aged 64, initially treated with etanercept then adalimumab because of psoriatic arthritis. During the observation, the loss of response to the anti-TNF drug was observed. During subsequent visits, whole blood was collected from the patient for molecular analysis based on the RTqPCR.

Conclusions. Molecular markers such as TNF- $\alpha$, TNFR1, TNFR2 seem to be useful for early detection of drug resistance and fit into the model of personalised medicine.
\end{abstract}

\section{STRESZCZENIE}

Wprowadzenie. Terapia anty-TNF, mimo molekularnego ukierunkowania działania, wiąże się ze zjawiskiem lekooporności. Sposobem na odpowiednio wczesną zmianę leczenia i zwiększenie jego skuteczności jest zastosowanie nowych markerów molekularnych.

Cel pracy. Przedstawienie klinicznych (PASI, BSA, DAS28, DLQI) i molekularnych (TNF- $\alpha, T N F R 1, T N F R 2)$ parametrów utraty skuteczności leczenia etanerceptem $u$ pacjentki z łuszczycą stawową.

Opis przypadku. Pacjentka, lat 64, początkowo leczona etanerceptem, następnie adalimumabem z powodu łuszczycy stawowej. Podczas obserwacji stwierdzono utratę odpowiedzi terapeutycznej na lek anty-TNF. W trakcie kolejnych wizyt pobierano od pacjentki krew pełną do analiz molekularnych z zastosowaniem metody RTqPCR. 
Wnioski. Molekularne markery, takie jak TNF- $\alpha$, TNFR1, TNFR2, wydają się użytecznym narzędziem wczesnej detekcji lekooporności i wpisują się w model medycyny personalizowanej.

Key words: anti-TNF therapy, psoriasis, resistance in therapy, molecular marker.

Słowa kluczowe: terapia anty-TNF, łuszczyca, lekooporność, marker molekularny.

\section{INTRODUCTION}

Psoriasis is an inflammatory disease that affects $1-3 \%$ of the society [1]. Parakeratosis manifests itself at microscopic level (histopathological examination), whereas a change in proinflammatory cytokine profile is a molecular indicator for psoriasis [2, 3].

Complex immunopathogenesis and nonhomogeneous level of disease intensity requires using various therapeutic strategies. In moderate and severe cases (PASI $>10$ or BSA $>10$ ) that resist conventional treatment, molecularly targeted anti-cytokine therapy is used [3,4]. Several well-characterized groups of anti-cytokine drugs may be differentiated: anti-TNF tumour necrosis factor $\alpha$ (etanercept, adalimumab, infliximab, certolizumab pegol, and golimumab), antiIL-17 (secukinumab, ixekizumab, and brodalumab) and anti-IL-12/23 (ustekinumab) [5, 6].

During biological therapy a loss of adequate response to treatment may occur [7]. It should be remembered that molecular changes anticipate phenotype changes, and thus, molecular marker systems gain in importance [8].

Etanercept is a fusion protein of a soluble TNF- $\alpha$ receptor and the Fc end of IgG1. It is characterized by an ability to neutralize the soluble TNF- $\alpha$. A 24-week non-stop therapy is recommended, whereby treatment efficacy should be determined after 12 weeks [4]. Adalimumab is a fully human monoclonal antibody neutralizing free and membrane-bound form of TNF- $\alpha$. Over $60 \%$ efficacy based on PASI is reported with therapy lasting longer than 60 weeks $[7,9]$.

\section{OBJECTIVE}

The aim of this paper is to discuss usefulness of examining TNF- $\alpha$ expression changes and its TNFR1 and TNFR2 as markers for early detection of loss of therapeutic response to anti-TNF drugs based on an example of a female patient suffering from psoriatic arthritis, in whom resistance to etanercept had been observed, and consequently, adalimumab was introduced.

\section{WPROWADZENIE}

Łuszczyca jest chorobą o podłożu zapalnym, która dotyczy 1-3\% społeczeństwa [1]. Parakeratoza to jej manifestacja na poziomie mikroskopowym (badanie histopatologiczne), natomiast molekularnym wykładnikiem łuszczycy jest zmiana profilu stężeń cytokin $[2,3]$.

Złożona immunopatogeneza oraz niejednorodny stopień nasilenia choroby wymagają stosowania różnych strategii terapeutycznych. W umiarkowanych oraz ciężkich przypadkach (PASI > 10 lub BSA > 10), niepoddających się leczeniu metodami konwencjonalnymi stosuje się ukierunkowaną na cele molekularne terapię antycytokinową [3, 4]. Można wyróżnić kilka dobrze scharakteryzowanych grup leków antycytokinowych: anty-TNF - czynnik martwicy nowotworu $\alpha$, tumor necrosis factor $\alpha$ (etanercept, adalimumab, infliksymab, certolizumab pegol, golimumab), anty-IL-17 (sekukinumab, iksekizumab, brodalumab) oraz anty-IL-12/23 (ustekinumab) [5, 6].

W trakcie terapii biologicznej może dojść do utraty adekwatnej odpowiedzi na leczenie [7]. Należy pamiętać, że zmiany molekularne wyprzedzają zmiany fenotypowe, a molekularne systemy markerowe zyskują na znaczeniu [8].

Etanercept jest białkiem fuzyjnym rozpuszczalnego receptora dla TNF- $\alpha$ oraz fragmentu Fc IgG1. Charakteryzuje się zdolnością neutralizowania rozpuszczalnej formy TNF- $\alpha$. Rekomenduje się prowadzenie terapii przez 24 tygodnie lub w sposób nieprzerwany, przy czym efektywność leczenia należy określić po 12 tygodniach [4]. Adalimumab jest w pełni ludzkim przeciwciałem monoklonalnym neutralizującym wolną i związaną z błoną komórkową formę TNF- $\alpha$. Ponad 60-procentową skuteczność opartą na wskaźniku PASI stwierdza się przy terapii dłuższej niż 60 tygodni $[7,9]$.

\section{CEL PRACY}

Celem pracy było omówienie przydatności badania zmian ekspresji TNF- $\alpha$ i jego receptorów TNFR1 i TNFR2 jako markerów wczesnej detekcji utraty odpowiedzi terapeutycznej na lek anty-TNF na przy- 


\section{CASE REPORT}

A 64-year-old female patient was treated for psoriatic arthritis initially with etanercept (18 months), and then with adalimumab (14 months) at Dermatology Clinic. Efficacy of the anti-TNF therapy based on molecular indicators was observed for 32 months. Evaluation of changes in $T N F-\alpha$ expression and its TNFR1 and TNFR2 was performed every 12 weeks (table 1) using real-time reverse transcription polymerase chain reaction (RT-qPCR). Beta-actin (ACTB) was used an endogenous control. Whole blood drawn prior to administering another drug dose constituted a sample for examination. RNA isolation was performed with the use of Fenozol reagent (A\&A, Biotechnology, Gdansk, Poland) according to manufacturer's instructions.

On the basis of obtained results it may be observed that during the etanercept therapy, $T N F-\alpha$ transcription activity increases with subsequent doses. Such a tendency is observed till the administration of the last but one etanercept dose. After the treatment was changed, with the sixth dose of adalimumab, a silencing of TNF- $\alpha$ expression may be observed as compared with expression reported with etanercept treatment. A relatively significant increase in expression is observed prior to administration of the $15^{\text {th }}$ adalimumab dose, however, after that time a constant decrease in expression of the discussed cytokine may be concluded. TNF- $\alpha$ expression is not reported inthe two last periods of observation. Regardless of antiTNF drug, a higher number of TNFR1 than TNFR2 kładzie pacjentki chorującej na łuszczycę stawową, u której wystąpiła oporność na etanercept, w wyniku czego wdrożono leczenie adalimumabem.

\section{OPIS PRZYPADKU}

Kobieta 64-letnia leczona z powodu łuszczycy stawowej w Klinice Dermatologii początkowo etanerceptem (18 miesięcy), a następnie adalimumabem (14 miesięcy). Obserwację skuteczności terapii anty-TNF opartą na wskaźnikach molekularnych prowadzono przez 32 miesiące. Zmiany ekspresji TNF- $\alpha$ i jego receptorów TNFR1 oraz TNFR2 oceniano co 12 tygodni (tab. 1) na podstawie techniki łańcuchowej reakcji polimeryzacji poprzedzonej odwrotną transkrypcją w czasie rzeczywistym (RTqPCR). Jako kontrolę endogenną wykorzystano $\beta$-aktynę (ACTB). Materiał do badań stanowiła krew pełna pobierana przed podaniem kolejnej dawki leku. Izolację kwasu rybonukleinowego przeprowadzono odczynnikiem Fenozol (A\&A Biotechnology, Gdańsk) zgodnie z rekomendacją producenta.

Na podstawie uzyskanych wyników można stwierdzić, że podczas terapii etanerceptem wraz z kolejnymi dawkami wzrasta aktywność transkrypcyjna TNF- $\alpha$. Taka tendencja utrzymuje się do podania przedostatniej dawki etanerceptu. Po zmianie sposobu leczenia przy szóstej dawce adalimumabu stwierdza się wyciszenie ekspresji $T N F-\alpha$ w porównaniu z ekspresją przy leczeniu etanerceptem. Relatywnie duży wzrost ekspresji TNF- $\alpha$ obserwuje się przed podaniem 15. dawki adalimumabu, jednak po tym czasie można stwierdzić jej stały spadek. W dwóch ostatnich

Table I. Changes in TNF- $\alpha$, TNFRI, TNFR2, and ACTB transcription activity during etanercept and adalimumab therapy in a female patient with psoriatic arthritis

Tabela I. Zmiany aktywności transkrypcyjnej TNF- $\alpha$, TNFRI, TNFR2, ACTB podczas terapii etanerceptem i adalimumabem u pacjentki z łuszczycowym zapaleniem stawów

\begin{tabular}{|c|c|c|c|c|c|c|c|c|c|}
\hline \multirow[t]{2}{*}{ Drug/Lek } & \multirow[t]{2}{*}{$\begin{array}{l}\text { Dose/ } \\
\text { Dawka }\end{array}$} & \multicolumn{4}{|c|}{$\begin{array}{c}\text { Number of copies/I } \mu g \text { RNA/ } \\
\text { Liczba kopii/I } \mu g \text { RNA }\end{array}$} & \multicolumn{4}{|c|}{$\begin{array}{l}\text { Clinical parameters of psoriasis severity/ } \\
\text { Parametry kliniczne nasilenia łuszczycy }\end{array}$} \\
\hline & & TNF & TNFRI & TNFR2 & АСТВ & DAS 28 & PASI & BSA & DLQI \\
\hline \multirow[t]{8}{*}{ Etanercept } & 12 & 1205 & 7424 & 28 & 16658228 & 3.12 & 16 & 16 & 5 \\
\hline & 23 & 11410448 & 9224 & 47 & 7574627 & 2.10 & 4.80 & 12 & 4 \\
\hline & 34 & 55608 I & 5220 & 62 & 333311 & 1.64 & 4.40 & 7 & 4 \\
\hline & 46 & 639241 & 15380 & 10 & 70506 & 1.73 & 4.40 & 7 & 4 \\
\hline & 58 & 876506 & 13934 & 7 & 15307 & 3.01 & 5.00 & 8 & 5 \\
\hline & 69 & 14683673 & 40020 & 52 & 94306 & 2.44 & 5.10 & 7 & 5 \\
\hline & 70 & 5440909 & 3036 & 14 & 13250 & 4.89 & 11 & 17 & 8 \\
\hline & 82 & 26117 & 33483 & 78 & 237667 & 4.74 & 19 & 30 & 11 \\
\hline \multirow[t]{6}{*}{ Adalimumab } & 6 & 9042 & 13030 & 176 & 11660 & 4.25 & 5 & 10 & 4 \\
\hline & 10 & 14126 & 16897 & 554 & 22059 & 2.68 & 1 & 6 & 3 \\
\hline & 15 & 103692 & 107538 & 3078 & 81923 & 3.92 & 3 & 9 & 12 \\
\hline & 21 & 27545 & 47750 & 1068 & 165136 & 3.66 & 7 & 12 & 12 \\
\hline & 27 & 0 & 0 & 0 & 8711 & 4.16 & 7 & 12 & 12 \\
\hline & 32 & 0 & 0 & 0 & 2151 & 3.94 & 7 & 12 & 12 \\
\hline
\end{tabular}


transcripts may be observed, however, dominance of TNFR1 over TNFR2 decreases during adalimumab therapy. ACTB expression reported during the entire observation confirms nativity of RNA extracts and correctness of mRNA amplification reaction of the analysed genes.

\section{DISCUSSION}

Observations made in this paper fit into the pattern of modern diagnostic and therapeutic strategies that emphasize individualistic approach to diagnostics and treatment. Such an approach is also based on the fact that molecular changes anticipate changes on phenotype level. An early detection of the loss of treatment response has become possible thanks to the development of molecular methods. They allow for increasing safety of therapies to a significant extent, and simultaneously maintaining their efficacy [8]. In the previous paper involving an in vitro model it was shown that changes at the transcriptome level after exposure of skin fibroblasts to adalimumab are possible to be detected after 2 hours of adding the drug to the culture. Moreover, the changes became less noticeable with prolonging the time of cell exposure to the drug [10].

Observations made by other research teams indicate validity of TNF- $\alpha$ expression pattern examination, and emphasize efficacy of pharmacotherapy targeted at cytokines in psoriatic patients [11].

The case described herein is special as it discusses the only patient with anti-TNF therapy, remaining under our supervision, in whom we have observed a different direction of drug resistance. Majority of our patients ceased to react to adalimumab after some time, and therefore, they had to switch to etanercept to good effect.

Clinical exponents of loss of adequate response to treatment with etanercept are increasing PASI and BSA values. Values of these indicators with administration of the last etanercept dose are higher than prior to treatment initiation. Having changed the therapy to adalimumab, and based on the above-mentioned indicators, a clinical improvement was noted. However, regardless of the anti-TNF drug used, DAS28 remains at the relatively same level.

Molecular analysis showed that, depending on the drug, the ratio of the number of copies of TNFR1 to TNFR2 transcripts is different (lower for etanercept), what suggests that receptor expression profile for TNF- $\alpha$ could constitute an indicator of intensification of inflammatory processes [12]. An analysis of expression pattern for TNFR1 and TNFR2 is taken into account as an indicator for treatment toxicity, and thereby, its safety $[13,14]$. okresach obserwacji nie stwierdza się ekspresji TNF- $\alpha$. Niezależnie od leku anty-TNF można zaobserwować większą liczbę transkryptów TNFR1 niż TNFR2, jednak przewaga TNFR1 nad TNFR2 zmniejsza się podczas terapii adalimumabem. Obecność podczas całej obserwacji ekspresji ACTB potwierdza natywność ekstraktów RNA oraz poprawność reakcji amplifikacji mRNA analizowanych genów.

\section{OMÓWIENIE}

Obserwacje poczynione w niniejszej pracy wpisują się $\mathrm{w}$ model nowoczesnych strategii diagnostyczno-terapeutycznych, w których podkreśla się indywidualizację podejścia do diagnostyki i leczenia. W takim ujęciu uwzględnia się też fakt, że zmiany molekularne wyprzedzają zmiany na poziomie fenotypu. Wczesna detekcja utraty odpowiedzi na leczenie stała się możliwa dzięki rozwojowi metod molekularnych. Pozwala to w znacznym stopniu zwiększyć bezpieczeństwo terapii, nie zmniejszając jej skuteczności [8]. W poprzedniej pracy na modelu in vitro wskazaliśmy, że zmiany na poziomie transkryptomu po ekspozycji komórek fibroblastów skóry na adalimumab są możliwe do wykrycia po 2 godzinach od dodania leku do hodowli. Ponadto w miarę wydłużania czasu ekspozycji komórek na lek zmiany te stawały się mniej zauważalne [10].

Obserwacje poczynione przez inne zespoły badawcze wskazują na zasadność badania wzoru ekspresji TNF- $\alpha$ i podkreślają efektywność farmakoterapii ukierunkowanej na tę cytokinę u pacjentów z łuszczycą [11].

Opisany przypadek jest wyjątkowy, ponieważ jest to jedyny pacjent leczony anty-TNF znajdujący się pod naszą obserwacją, u którego stwierdzono odmienny kierunek lekooporności. Większość naszych pacjentów po pewnym czasie przestawała reagować na adalimumab, dlatego zmieniano ten lek na etanercept $\mathrm{z}$ dobrym skutkiem.

Klinicznym wykładnikiem utraty adekwatnej odpowiedzi na leczenie etanerceptem są wzrastające wartości PASI oraz BSA. Wskaźniki te w momencie podania ostatniej dawki etanerceptu osiągnęły większą wartość niż przed rozpoczęciem leczenia. Po zmianie terapii na adalimumab na podstawie wspomnianych wskaźników stwierdzono poprawę kliniczną. Niezależnie jednak od stosowanego leku anty-TNF wskaźnik DAS28 jest na względnie podobnym poziomie.

Analiza molekularna wskazała, że w zależności od leku wielkość stosunku liczby kopii transkryptu TNFR1 do TNFR2 jest różna (mniejsza dla etanercep$\mathrm{tu})$, co sugeruje, że profil ekspresji receptorów dla TNF- $\alpha$ może stanowić wskaźnik nasilenia procesów zapalnych [12]. Analiza wzoru ekspresji receptorów TNFR1 i TNFR2 jest brana pod uwage jako wykładnik toksyczności leczenia i jego bezpieczeństwa $[13,14]$. 
Perhaps the different receptor expression profiles depending on the drug used found by us are a result of different structure and activity mechanism of adalimumab and etanercept $[3,15]$. However, these observations show that anti-TNF therapy affects TNF- $\alpha$-induced signalising pathways by changing TNFR1 and TNFR2 expression. Moreover, it should be remembered that TNFR 1 is basically expressed by a larger cell pool and that a given anti-TNF drug affects the kind of biological processes induced by TNF- $\alpha[16]$.

To the $15^{\text {th }}$ dose of adalimumab one could observe an increase in TNF- $\alpha$ expression as compared with the expression noted with the previous dose, and then, a decrease in TNF- $\alpha$ transcript activity down to 0 copies $/ 1 \mu \mathrm{g}$ RNA with the $27^{\text {th }}$ drug dose. Initially, such a trend was observed also when the drug was changed, however, the last two measurements indicate a total neutralization of TNF- $\alpha$ transcript, and thus, efficacy of anti-cytokine therapy. Persisting relatively high level of cytokine expression when the drug was changed may explain the body compensation mechanism aiming at homeostasis. Or perhaps the lack of efficacy of the primary treatment was connected with an intensified TNF- $\alpha$ secretion that was not neutralized [17].

An increased TNF- $\alpha$ concentration may also result from a long serum half-life of etanercept [18].

Loss of adequate response to treatment with etanercept may have several causes. Also, several factors that potentially weaken treatment efficacy may simultaneously occur in a given patient. Different activities of both analysed anti-TNF drugs may constitute a potential cause for the discussed drug resistance. Etanercept shows an ability to neutralize only a soluble $T N F-\alpha$, whereas adalimumab neutralizes both free and membrane-bound TNF- $\alpha$ $[4,7,9]$. Moreover, it is indicated that serum IL-17 concentration prior to a therapy with anti-cytokine drugs, including etanercept, determines the odds for the therapy success [19]. Al-Gareeb et al. observed also a lack of adequate response to etanercept in patients suffering from rheumatoid arthritis [20]. On the basis of their own observations, Pappas et al. also report a lack of response to anti-TNF therapy in part of their patients [21]. The level of response to treatment may result from individual variability associated with the rate of drug metabolism [22], which depends on the genotype for CYP2D 6 gene [23]. Given these facts, perhaps the described patient was a rapid metabolizer of etanercept, and the lack of proper and anticipated response to treatment resulted from insufficient doses of the anti-TNF drug in relation to the pace of its metabolizing.
Niewykluczone, że stwierdzone przez nas odmienne profile ekspresji receptorów w zależności od stosowanego leku są wynikiem różnej budowy i mechanizmu działania adalimumabu i etanerceptu $[3,15]$. Obserwacje te wskazują jednak, że terapia anty-TNF wpływa na szlaki sygnałowe indukowane przez TNF- $\alpha$ poprzez zmiany ekspresji receptorów TNFR1 i TNFR2. Ponadto warto wiedzieć, że TNFR1 zasadniczo jest wyrażany przez większą pulę komórek oraz że dany lek anty-TNF wpływa na rodzaj procesów biologicznych indukowanych przez TNF- $\alpha$ [16].

Do 15. dawki adalimumabu można było zaobserwować wzrost ekspresji TNF- $\alpha$ w porównaniu z ekspresją stwierdzaną przy dawce wcześniejszej, a następnie zmniejszanie aktywności transkrypcyjnej TNF- $\alpha$ aż do wartości 0 kopii/1 $\mu \mathrm{g}$ RNA przy 27. dawce leku. Początkowo również przy zmianie leku obserwuje się taką tendencję, jednak dwa ostatnie pomiary wskazują na całkowitą neutralizację transkryptu TNF- $\alpha$, a także skuteczność terapii antycytokinowej. Utrzymujący się stosunkowo wysoki poziom ekspresji cytokiny przy zmianie leku można tłumaczyć mechanizmem kompensacyjnym organizmu i dążeniem do osiągnięcia homeostazy. Niewykluczone również, że brak skuteczności pierwotnego leczenia wiązał się z nasilającą się sekrecją TNF- $\alpha$, który nie ulegał neutralizacji [17].

Podwyższone stężenie TNF- $\alpha$ może być również wynikiem długiego okresu półtrwania etanerceptu w surowicy [18].

Utrata adekwatnej odpowiedzi na leczenie etanerceptem może mieć kilka przyczyn. Niewykluczone, że u danego pacjenta może występować jednocześnie kilka potencjalnych czynników osłabiających skuteczność terapii. Odmienny sposób działania obu analizowanych inhibitorów TNF może stanowić przyczynę omawianej lekooporności. Etanercept ma zdolność neutralizowania tylko rozpuszczonej formy TNF- $\alpha$, a adalimumab neutralizuje zarówno wolną, jak i związaną z błoną komórkową formę TNF- $\alpha[4,7,9]$. Wskazuje się również, że stężenie IL-17 w surowicy przed rozpoczęciem terapii lekami antycytokinowymi, w tym etanerceptem, określa szansę powodzenia terapii [19]. Al-Gareeb i wsp. zaobserwowali brak adekwatnej odpowiedzi na etanercept u pacjentów chorujących na reumatoidalne zapalenie stawów [20]. Również Pappas i wsp. na podstawie obserwacji stwierdzili brak odpowiedzi na terapię anty-TNF u części pacjentów [21]. Stopień odpowiedzi na leczenie może wynikać ze zmienności osobniczej związanej z szybkością metabolizowania leków [22], która zależy od genotypu genu CYP2D6 [23]. Niewykluczone, że przedstawiona pacjentka była szybkim metabolizerem etanerceptu, a brak właściwej i spodziewanej odpowiedzi na leczenie wynikał z niewystarczających dawek leku anty-TNF w stosunku do tempa jego metabolizowania. 


\section{CONCLUSIONS}

Treatment safety and efficacy are possible thanks to markers, whose detection allows for changing treatment methods before observing clinical phenotypic changes. The described case and analysis of TNF- $\alpha, T N F R 1$ and TNFR2 expression show that a possible loss of drug sensitivity has to be taken into account even in cases of focused anti-cytokine treatment. Furthermore, the profile of analysed genes indicated their usefulness as supplementary molecular markers of response to treatment.

\section{CONFLICT OF INTEREST}

The authors declare no conflict of interest.

\section{WNIOSKI}

Bezpieczeństwo i skuteczność terapii są możliwe dzięki markerom, których wykrycie pozwala na zmianę sposobu leczenia przed zaobserwowaniem klinicznych, fenotypowych zmian. Opisany przypadek i analiza ekspresji TNF- $\alpha$, TNFR1, TNFR2 wskazują, że nawet podczas ukierunkowanego leczenia antycytokinowego trzeba pamiętać o możliwości wystąpienia utraty wrażliwości na lek. Ponadto profil analizowanych genów wskazuje na ich użyteczność jako uzupełniających, molekularnych markerów odpowiedzi na leczenie.

\section{KONFLIKT INTERESÓW}

Autorzy nie zgłaszają konfliktu interesów.

\section{References}

\section{Piśmiennictwo}

1. Tsoi L.C., Stuart P.E., Tian C., Gudjonsson J.E., Das S., Zawistowski M., et al.: Large scale meta-analysis characterizes genetic architecture for common psoriasis associated variants. Nat Commun 2017, 24, 1-8.

2. Szepietowski J., Adamski Z., Chodorowska G., Kaszuba A., Placek W., Rudnicka L., et al.: Leczenie łuszczycy - rekomendacje ekspertów Polskiego Towarzystwa Dermatologicznego. Część druga: łuszczyca umiarkowana do ciężkiej. Dermatol Rev/ Przegl Dermatol 2014, 101, 455-472.

3. Michalak-Stoma A., Bartosińska J., Kowal M., Juszkiewicz-Borowiec M., Gerkowicz A., Chodorowska G.: Serum levels of selected Th17 and Th22 cytokines in psoriatic patients. Dis Markers 2013, 35, 625-631.

4. Szepietowski J., Adamski Z., Chodorowska G., Gliński W., Kaszuba A., Placek W., et al.: Rekomendacje Polskiego Towarzystwa Dermatologicznego dotyczące stosowania leków biologicznych w łuszczycy zwyczajnej i stawowej (łuszczycowym zapaleniu stawów). Dermatol Rev/Przegl Dermatol 2010, 97, 1-13.

5. Wcisło-Dziadecka D., Zbiciak M., Brzezińska-Wcisło L., Mazurek U.: Anti-cytokine therapy for psoriasis - not only TNF blockers. Overview of reports on the effectiveness of therapy with IL12/IL23 and T and B lymphocyte inhibitors. Post Hig Med Dosw 2016, 70, 1198-1205.

6. Wcisło-Dziadecka D., Zbiciak-Nylec M., Brzezińska-Wcisło L., Bębenek A.K., Kaźmierczak A.: Newer treatments of psoriasis regarding IL-23 inhibitors, phospodiesterase 4 inhibitors, and Janus kinase inhibitors. Derm Ter 2017, 30, 1-8.

7. Roda G., Jharap B., Neeraj N., Colombel J.F.: Loss of response to anti-TNFs: definition, epidemiology, and management. Clin Transl Gastroenterol 2016, 7, e135.

8. Le Tourneau C., Kamal M., Tsimberidou A.M., Bedard P., Pierron G., Callens C., et al.: Treatment algorithms based on tumor molecular profiling: The essence of precision medicine trials. J Natl Cancer Inst 2015, 108, djv362.

9. Pełka M., Broniarczyk-Dyła G.: Zastosowanie leków biologicznych w dermatologii. Postepy Dermatol Alergol 2007, 24 , 35-41.

10. Wcisło-Dziadecka D., Grabarek B., Zmarzły N., Skubis A., Sikora B., Kruszniewska-Rajs C., et al.: Influence of adalimumab on the expression profile of genes associated with histaminergic system in the skin fibroblasts in vitro. BioMed Research Int 2018, 2018, 1582173

11. Shveta, Agarwal K., Chander R., Agarwal S.: Serum levels of se-selectin, TNF-alpha and IL-1beta in patients of psoriasis before and after topical therapy in patients of psoriasis. IJCR 2017, 9, 55837-55840.

12. Heilig B., Wermann M., Gallati H., Brockhaus M., Berke B., Egen O., et al.: Evaluation TNF receptor plasma concentrations in patients with rheumatoid arthritis. Clin Investig 1992, 70, $22-27$.

13. Gola J., Strzałka-Mrozik B., Kruszniewska-Rajs C., Janiszewski A., Skowronek B., Gagoś M., et al.: A new form of amphotericin B - the complex with copper (II) ions - downregulates sTNFR1 shedding and changes the activity of genes involved in TNF-induced pathways: AmB-Cu2+ downregulates sTNFR1 shedding and changes the activity of genes involved in TNF-induced pathways. Pharmacol Rep 2017, 69, 22-28.

14. Gola J., Strzałka-Mrozik B., Wieczorek E., Kruszniewska-Rajs C., Adamska J., Gagoś M., et al.: Amphotericin B-copper (II) complex alters transcriptional activity of genes encoding transforming growth factor-beta family members and related proteins in renal cells. Pharmacol Rep 2017, 69, 1308-1314.

15. Kwiek B., Narbutt J., Sysa-Jędrzejowska A., Lagner A., Lesiak A.: Long-term treatment of chronic plaque psoriasis with biological drugs can control platelet activation: argeting the bridge between inflammation and atherothrombosis. Postepy Dermatol Alergol 2017, 34, 131-137.

16. Webb K.C., Tung R., Winterfield L.S., Gottlieb A.B., Eby J.M., Henning S.W.: Tumour necrosis factor-alpha inhibition can stabilize disease in progressive vitiligo. Br J Dermatol 2015, 173, 641-650.

17. Szeremeta A., Olczyk K.: Tumor necrosis factor alpha antagonists in the treatment of the patients with rheumatoid arthritis. Reumatologia 2012, 50, 438-443. 
18. Madhusudan S., Foster M., Muthuramalingam S.R., Braybrooke J.P., Wilner S., Kaur K., et al.: A phase II study of etanercept (Enbrel), a tumor necrosis factor a inhibitor in patients with metastatic brest cancer. Clin Cancer Res 2004, 10, 6528-6534.

19. Fitz L., Zhang W., Soderstrom C., Fraser S., Lee J., Quazi A., et al.: Association between serum interleukin-17A and clinical response to tofacitinib and etanercept in moderate to severe psoriasis. Clin Exp Dermatol 2018, 43, 790-797.

20. Al-Gareeb A.I.A., Gorial F.I., Mahmood A.S.: Niclosamide as an adjuvant to etanercept in treatment patients with active rheumatoid arthritis: an 8-week randomized controlled pilot study. Clin Rheumatol 2018, doi: 10.1007/s10067-018-4164-5 [Epub ahead of print].

21. Pappas D.A., Gerber R.A., Litman H.J., Gruben D., Geier J., Hua W.D.: Delayed treatment acceleration in patients with rheumatoid arthritis who have inadequate response to initial tumor necrosis factor inhibitors: data from the Corrona Registry. Am Health Drug Benefits 2018, 11, 148-158.

22. Rychlik-Sych M., Barańska M., Skrętowicz J.: Clinical significance of pharmacogenetics in dermatological diseases. Przegl Lek 2012, 69, 120-124.

23. Czarnecka A., Niewiński P., Orzechowska-Juzwenko K., Maj J., Hurkacz M.: Genotyp oksydacji CYP2D6 jako czynnik zwiększający ryzyko wystąpienia łuszczycy zwykłej. Derm Klin 2005, 7, 25-27.

Received: 10.06 .2018

Accepted: 17.08 .2018

Otrzymano: $10.06 .2018 \mathrm{r}$

Zaakceptowano: $17.08 .2018 \mathrm{r}$.

How to cite this article

Wcisło-Dziadecka D.L., Grabarek B., Brzezińska-Wcisło L., Mazurek U.: Drug resistance in anti-TNF therapy of psoriatic arthritis. Dermatol Rev/Przegl Dermatol 2018, 105, 625-631. DOI: https://doi.org/10.5114/dr.2018.79175. 